\title{
STRENGTHENING THE RIGHTS OF SEXUALLY ABUSED CHILDREN IN FRONT OF THE EUROPEAN COURT FOR HUMAN RIGHTS - A TALE OF JUSTICE, FAIRNESS AND CONSTANT NORMATIVE EVOLUTION*
}

\author{
Dalida Rittossa, PhD, Assistant Professor \\ University of Rijeka, Faculty of Law \\ Hahlić 6, Rijeka, Croatia \\ dalida@pravri.hr
}

\begin{abstract}
In recent years, numerous studies have focused at the phenomenon of child sexual abuse (hereinafter, the CSA) offering valid conclusions about its phenomenological structures, etiological causes and impact on victims and society as a whole. Although the bulk of research has furthered our understanding of different aspects of CSA, scientific work that would focus on child victims' rights from constitutional and criminal law perspective is still scarce. Seeking to fill the noted gap, the author presents the first academic study on standards for protection of sexually abused children's rights set by the European Court for Human Rights (hereinafter, the ECtHR or the Court). Relaying on Faye Jacobsen set of blended methodologies, 10 judgments related to protection of rights of sexually victimised children are retrieved from the HUDOC system and analysed in detail. A special attention has been paid to safeguards and guarantees under the Article 3 and 8 of the Convention as well as their critical evaluation with respect to already established constitutional legal solutions. The qualitative analysis has revealed that judicial activism in the Strasbourg Court case law has been for years a driving force to enhance the protection of sexually abused children, and that today, this protection has significantly evolved, forming a concept of particularly vulnerable victims and child-sensitive approach within the context of child friendly justice. Although the evolutive line of the scope and content of CSA protection standards created by the Court can be noted, judicial reasoning techniques behind their development are susceptible to criticism.
\end{abstract}

Keywords: child sexual abuse, the European Court for Human Rights, development of normative standards, protection of child victim's rights, vulnerability

This work has been fully supported by the University of Rijeka under the project number [uniri-drustv-18-86]. The article also presents preliminary research results of the Croatian Science Foundation project "Life in the Time of COVID-19 - Social Implications on the Security and Well-Being of Vulnerable Groups in the European Context" 


\section{INTRODUCTORY REMARKS - THE PHENOMENON OF CHILD SEXUAL ABUSE AND THE NEED FOR MORE SPECIFIC RESEARCH}

In scientific and general community, a widely accepted consensus exists that CSA is a highly negative social phenomenon with multiple long and short-term consequences. Sexual crimes against children are considered as one of the most serious and heinous prohibited behaviours that eclipse all other crimes. ${ }^{1}$ Once the crime is discovered, the awareness of it deeply convulses a community. In most cases, there is a strong need not to acknowledge the incident or to believe that such cases are separate, individual excesses which usually happen to someone else. Recent studies have shown that broader societal denial of the scope of the problem, together with other negative factors, may induce embarrassment, stigma, and fear that can silence victims and dissuade members of their family from reporting the offence. ${ }^{2}$ Not surprisingly, the infringement of child's sexual integrity has been, therefore, vailed with secrecy and disavowal for years. In the last 1970s, the social silence was broken by humanitarian organizations, for instance the UN, UNICEF and the WHO, and women movements that begun to draw attention to the CSA and correlated social problems such as interpersonal violence and social violence and the magnitude of their impact on women and children. A number of studies soon followed questioning the abuse and sexual exploitation of children from numerous standpoints trying to estimate its phenomenological extent and occurrence variations as well as etiological characteristics. ${ }^{3}$ Due to the bulk of research in the field of criminal law, medicine, medical health, psychology, sociology, the CSA turned out to be "the most researched form of child maltreatment". ${ }^{4}$

Almost five decades of empirical and theoretical research has broadened our knowledge about different aspects of CSA and offered a valid basis for framing comprehensive social policies. According to numerous studies, subjecting children to sexual acts may cause a wide range of psychological and interpersonal problems as well as immediate and long-term detrimental health consequences. Vic-

Adler, A., The Perverse Law of Child Pornography, Columbia Law Review, vol. 101, no. 2, 2001, pp. $227-228$

2 Azzopardi, C. et al., A Meta-Analysis of the Prevalence of Child Sexual Abuse Disclosure in Forensic Settings, Child Abuse \& Neglect, vol. 93, no. 2, 2019, p. 292

3 Bidarraa, Z. et al., Co-Occurrence of Intimate Partner Violence and Child Sexual Abuse: Prevalence, Risk Factors and Related Issues, Child Abuse \& Neglect, vol. 55, no. 2, 2016, pp. $10-11$

4 Ajduković, M. et al., Gender and Age Differences in Prevalence and Incidence of Child Sexual Abuse in Croatia, Croatian Medical Journal, vol. 54, 2013, p. 470 
tims of CSA can experience anxiety problems, ${ }^{5}$ depression, ${ }^{6}$ post-traumatic stress disorder, ${ }^{7}$ aggression and substance abuse. ${ }^{8}$ The suicidality is also associated with sexual abuse during the childhood. Angelakis and a group of authors highlighted that their comprehensive metanalytical research showed a clear causal connection between CSA and suicidal ideation and suicide attempts in adult survivors. ${ }^{9}$ The list of negative consequences is not exhausted, and different studies revile that CSA presents a significant potential for revictimization later in life, ${ }^{10}$ unwanted pregnancy and poor overall health. ${ }^{11}$ Although research conclusions on CSA may vary in scientific literature due to inconsistent CSA definitions, methodological issues like use of retrospective studies or official criminal justice statistics, the CSA professionals mutually agree that we are dealing with a serious, pervasive, worldwide phenomenon, a sort of social continuance that can be found throughout the years in different cultures and among different social groups. Therefore, the protection of victims' rights should be positioned at the forefront of human rights policies.

\section{METHODOLOGICAL ATTRIBUTES AND CONCEPTUALISATION OF THE RESEARCH SAMPLE}

Although the growth associated with CSA research has increased in both the quantity and the quality, scientific analysis of child victims' rights and adequateness of relevant criminal offences from a legal perspective fall behind. The same trend can be noted in Croatian research community. The systematic literature research using the Hrčak and Heinonline electronic databases revealed that only five scientific articles scrutinising the criminal justice responses to CSA were published in Croatian scientific journals between 1993 and 2020, none of them focusing on the EC-

5 Manigliol, R., Child Sexual Abuse in the Etiology of Anxiety Disorders: A Systematic Review of Reviews, Trauma, Violence \& Abuse, vol. 14, no. 2, 2013, p. 96

6 Judgement D.P. \& J.C. v. the United Kingdom (2003)

7 Hébert, M. et al., Agression sexuelle et violence dans les relations amoureuses: Le rôle médiateur du stress post-traumatique, Criminologie, vol. 50, no. 1, Lagression sexuelle commise sur des mineurs: les victimes, les auteurs, 2017, p. 160

8 Domhardt, M. et al., Resilience in Survivors of Child Sexual Abuse: A Systematic Review of the Literature, Trauma, Violence \& Abuse, vol. 16, no. 4, 2015, p. 482

9 Angelakis, I. et al., Childhood Maltreatment and Adult Suicidality: A Comprehensive Systematic Review with Meta-Analysis, Psychological Medicine, vol, 49, 2019, p. 1060

10 Walker, H. et. al., The Prevalence of Sexual Revictimization: A Meta-Analytic Review, Trauma, Violence \& Abuse, vol. 20, no. 1, 2019, p. 75

11 Hilden, M. et al., A History of Sexual Abuse and Health: A Nordic Multicentre Study, BJOG: an International Journal of Obstetrics and Gynaecology, vol. 111, 2004, p. 1126 
tHR practice. ${ }^{12}$ However, legal researchers specialising in theoretical conceptualisation and practical analysis of the ECtHR jurisprudence have long acknowledged the significance of this Court. According to Letnar Černič, the Strasbourg Court was transformed "from Sadurski's "benign paradox" to a fully-fledged human rights court addressing the most heinous human rights violations". ${ }^{13}$ The Court has evolved into the largest judicial entity in the world with a clear international profile and Court's judgments have had a significant influence over the national legislation and court practice. Moreover, when certain legal issues are subjected to close scrutiny and involved in a heavy debate, the Court influence may overpass its jurisdictional boundaries and may be used as an argumentation tool in other human rights systems, and additionally, in the global human rights discourse. ${ }^{14}$ Children rights advocates have also recognised the ECtHR influence as a crucial factor in children's rights development. Even though in recent years the increase is noted in number of published scholarly works dedicated to the ECtHR case law, to the best of author's knowledge, this is the first academic study looking into the standards for protection of sexually abused children's rights set by the Court.

Having all this in mind, the aim of this study is, first of all, to research the prevalence of CSA cases in front of the ECtHR. Using the quantitative methodology, we will reveal the number of cases that reached the Court in Strasbourg and were adjudicated from criminal justice perspective. Moreover, the qualitative linguistic analysis will identify how the Court reasoning, in interpreting the Convention, has created the scope and content of CSA protection standards, which should be implemented in criminal justice systems operating in the state parties to the Convention. The final goal of the current study is to identify evolving trends in defining these standards, and with critical scrutiny, to explore whether the new standards, e.g. the concept of vulnerability and child-sensitive approach, erode

12 Kovčo Vukadin, I., Organizirani kriminalitet: pedofilija i prostitucija, Hrvatski ljetopis za kazneno pravo i praksu, vol. 5, no. 2, 1998, pp. 641 - 679; Kovco Vukadin, I., Stigmatizacija počinitelja seksualnih delikata, Zbornik Pravnog fakulteta Sveučilišta u Rijeci, vol. 24, no, 2, 2003, pp. 819 - 842; Radić, I.; Radina, A., Zaštita od nasilja u obitelji: obiteljskopravni, prekršajnopravni i kaznenopravni aspekt, Zbornik radova Pravnog fakulteta u Splitu, vol. 51, no. 3, 2014, pp. 727 - 754; Rittossa, D., Seksualni delikti na štetu djece: hrvatski kaznenopravni okvir kroz prizmu zahtjeva iz Direktive 2011/93/EU, Hrvatski ljetopis za kaznene znanosti i praksu, vol. 25, no. 1, 2018, pp. 29 - 63; Rittossa, D., Kažnjavanje počinitelja najtežih seksualnih delikata na štetu djece u RH: zakonski okviri i postojeća sudska praksa, Hrvatski ljetopis za kaznene znanosti i praksu, vol. 25, no. 2, 2018, pp. 417 - 445

13 Letnar Černič, J., Impact of the European Court of Human Rights on the Rule of Law in Central and Eastern Europe, Hague Journal on the Rule of Law, vol. 10, 2018, p. 113 citing Sadurski, W., Partnering with Strasbourg: Constitutionalisation of the European Court of Human Rights, The Accession of Central and East European States to the Council of Europe, and the Idea of Pilot Judgments, Human Rights Law Review, vol. 9, no. 3, 2009, p. 409

14 Procaccini, K., C., Constructing the Right Not to Be Made a Refugee at the European and Inter-American Courts of Human Rights, Harvard Human Rights Journal, vol. 22, no. 2, 2009, p. 273 
already established doctrinal institutes in ECtHR jurisprudence, e.g. the margin of appreciation. The quantitative and qualitative methods present a simplified version of Faye Jacobsen set of blended methodologies to explore children's rights in the ECtHR practice in a wider context. ${ }^{15}$

In order to apply the first nominated research method, HUDOC database was searched using a keywords' search strategy. The keywords "child", "sexual abuse", "sexual assault", "criminal offence" and "crime" were carefully chosen to build the query given that the enumerated keywords are the most cited key terms in research papers on CSA. Bearing in mind all the factors that may impact the formulation and the execution of the query to retrieve cases from the HUDOC system, the terms from the list of keywords were used individually as well as in combination for coding. After the exclusion of irrelevant and repeated cases, the query in the HUDOC database revealed that there have been 10 judgments related to protection of sexually abused children's rights, ${ }^{16} 3$ of them holding that there was no violation of the Convention ${ }^{17}$ and remining 7 confirming the violation of relevant Convention Articles. ${ }^{18}$

The research results clearly indicate that the child protection against sexual abuse has not been an issue that dominates Court's adjudication processes. It seems that the discourse related to child's rights not to be sexually abused that had surfaced in international policies and human rights movements almost half a century ago did not substantially reflect on the ECtHR case law. The first application related to child victim's rights in a sexual abuse case had been lodged with the European Commission of Human Rights on 12 February 1997, and almost 2 years later

15 Faye Jacobsen, A., Children's Rights in the European Court of Human Rights - An Emerging Power Structure, International Journal of Children's Rights, vol. 24, 2016, pp. $548-574$

16 The case of $Z$ and Others $v$. the United Kingdom (2001) was not included within the research sample due to the fact that the case concerned overall ill-treatment of four child applicants who had suffered appalling neglect over an extended period and physical and psychological abuse directly attributable to a violent criminal offense. Two of them had also shown signs of sexual abuse but the judgment is silent on the issue of its nature and intensity. Moreover, the inclusion criteria were not met in case of $X$ and $Y v$ the Netherlands (1985) bearing in mind that the central issue was whether the Netherland's criminal justice system offered the protection against sexual abuse of persons with mental difficulties over the age of 16 , a criminal offence not belonging to the category of sexual offences against children. In K.U. v. Finland (2009), the ECtHR concluded that online bullying of 13-year-old boy had made him a target for approaches by paedophiles, and therefore, amounted to invasion of his private life under Article 8 of the Convention. Due to the nature of violation, the case in question was left out of the research sample

17 Judgement $A$ and B v. Croatia (2019); M.P. and Others v. Bulgaria (2012); D.P. \& J.C. v. the United Kingdom, op. cit., note 6

18 Judgement M.S. v. Ukraine (2017); M.G.C. v. Romania (2016); Y. v. Slovenia (2015); O'Keeffe v. Ireland (2014); Söderman v. Sweden (2013); C.A.S. and C.S. v. Romania (2012); M.C. v. Bulgaria (2004) 
transmitted to the Court. ${ }^{19}$ The second case, M.C. v. Bulgaria, had originated in an application by the end of the same year, and reached the Court's agenda a year later. ${ }^{20}$ In 2005, the ECtHR received another application raising several complaints alleging repeated rape of a seven year old boy ${ }^{21}$ and in next 10 years all the other cases followed.

Although the small number of ECtHR decisions concerning the CSA cases might be expected due to the procedural constraints imposed by the principle of subsidiarity originating from Article $35 \$ 1$ of the Convention, ${ }^{22}$ the scarcity of the case law confirms that criminal justice reports underestimate the CSA prevalence. The significant number of cases remain unreported, and therefore, unknown to state's prosecutorial bodies. Moreover, reporting incidences of CSA depends on a set of diverse and interrelated factors emerging from political, societal and cultural currents. As the judges in dissent in O'Keeffe $v$. Ireland rightly pointed out, the silence creates the major difficulty in investigating sexual child abuse. ${ }^{23}$ Even if the case is successfully reported, a pathway that leads to the ECtHR might be paved with problems and obstacles. In the era of child right's industry, children are still predominantly seen as sub-human or not-yet-fully-human and their rights are defined in terms of care, needs and special protection. While depending on parents, guardians, family members, educators and state agents, children are entitled to rights which do not have the same power strength as those recognised to adults. ${ }^{24}$ Due to the absence of specific constitutional provisions and provisions within the Convention acknowledging children's rights, these rights are largely "invisible". ${ }^{25}$ It is of no surprise that children rarely have a status of applicant before the ECtHR. $^{26}$

19 Judgement D.P. \& J.C. v. the United Kingdom, op. cit., note 6

20 Judgement M.C. v. Bulgaria, op. cit., note 18

${ }_{21}$ Judgement C.A.S. and C.S. v. Romania, op. cit., note 18

22 The scope of the Article 35 is to promote and establish the subsidiarity of the ECtHR case law to national law. The states have obligation to protect human rights defined in the Convention first and foremost within their own legal systems. By reading the Article 35 in conjunction with Article 13, it comes to the view that it is the obligation of the state to provide an effective remedy at the national level for violation of Convention rights before the involved citizen has to find a recourse in international machinery of applications with the ECtHR

23 Joint partly dissenting opinion in O'Keeffe v. Ireland, op. cit., note 18

24 Alderson, P., Children's rights and power, in: Jones, S., (ed.) 30 Years of Social Change, London, Philadelphia, 2018, p. 81

25 Collins, T. M., International Child Rights in national Constitutions: Good Sense or Nonsense for Ireland, Irish Political Studies, vol. 28, No. 4, 2013, p. 594

26 Faye Jacobsen, op. cit., note 15, p. 553 
Bearing in mind that children generally have to count on others to present their claims and represent their interests, the Court has rejected the restrictive, technical approach in interpreting the position of children as individual applicants under Article 34 of the Convention. According to the Court, any serious issues vis-à-vis respect for child's rights, comprising the right to an effective investigation into the sexual abuse, should be examined. ${ }^{27}$ Children's representation in national court and ECtHR proceedings is, without any doubts, highly necessary, however, at the same time, it might enfeeble the power of child participation rights with respect to access to courts and court proceedings. In order to ameliorate the unavoidable dichotomy, the power and relationship between children and adults have to be put in the right balance especially if there is a risk of invoking child's rights in instrumental way. The qualitative analysis of the ECtHR judgments recognising rights of sexually abused children will show whether the standards set by the Court have offered such a valid solution or simply disregarded the necessity to moderate sexually abused children's rights in accordance with higher constitutional principles of fairness and justice.

\section{THE ECTHR CASE LAW - CRUCIAL POINTS FOR THE PROTECTION OF RIGHTS OF SEXUALLY VICTIMISED CHILDREN}

\subsection{Convention Rights Violations and Discourse on State Obligations in CSA Cases}

A detailed analysis of the CSA cases discussed in front of the ECtHR has revealed that the attack on sexual integrity of a child may present a violation of prohibition of torture (Article 3$)^{28}$ or right to respect for private and family life (Article 8$)^{29}$ or both ${ }^{30}$ and in certain cases the right to an effective remedy (Article 13). ${ }^{31}$ According to Article 3, "no one shall be subjected to torture or to inhuman or degrading treatment or punishment." 32 The legal construct behind the cited article demands a mandatory and complete elimination of acts that violate the right to personal integrity and dignity of an individual. In legal doctrine and court practice the complete and mandatory wording has been transformed in a mutual consensus

\footnotetext{
27 Judgement M.S. v. Ukraine, op. cit., note 18

28 Judgement O'Keeffe $v$. Ireland, op. cit., note 18

29 Judgement M.S. v. Ukraine, op. cit., note 18; Söderman v. Sweden, op. cit., note 18

30 Judgement C.A.S. and C.S. v. Romania, op. cit., note 18; M.C. v. Bulgaria, op. cit., note 18; M.G.C.v. Romania, op. cit., note 18; Y. v. Slovenia, op. cit., note 18

31 Judgement D.P. \&J.C. v. The United Kingdom, op. cit., note 6; O'Keeffe v. Ireland, op. cit., note 18

32 Article 3 ECHR
} 
that the rights under Article 3 are erga omnes rights that have absolute and nonderogable nature even in situations of emergency, such as war, threat of war, terrorism or similar public danger menacing the life of the nation..$^{33}$ Consequently, the prohibition of torture may not be overpassed with measures curtailed under the principle of proportionality and balancing of state and individual interests, nor can it be subjected to derogation under Article 15 or constructed according to victim's status. The highest level of protection associated with the rights envisaged in Article 3 derives from firm standing that these rights reflect "fundamental values of the democratic societies making up the Council of Europe". ${ }^{34}$

The normative parameter of freedom from ill-treatment as to Article 3 refers to various forms of conduct divided in three different cohorts depending on their gravity. The torture should cover the most atrocious forms of ill-treatment while lesser gravity is expected in case of inhuman and degrading treatment. The Court has established a notable practice on determining what kind of maltreatment falls within the specific Article 3 category, and in view of the firmly rooted principle in its case law that the Convention "is a living instrument which must be interpreted in the light of present-day conditions", ${ }^{35}$ forged the rule that prohibited acts could be classified differently in future as to increase the standards of protection of $\mathrm{Ar}$ ticle 3 rights. ${ }^{36}$ No matter the considerable attention given to these issues in its previous practice, the Court is silent as to defining the nature of CSA and evaluating its severity according to the three-tier scale of Article 3 prohibited forms of ill-treatment. The Court is confident that serious acts such as rape and other forms of sexual abuse of children, including sexual battery, present a direct attack on fundamental values, and consequently, fall within the ambit of Article $3 .{ }^{37} \mathrm{~A}$ glimpse of indications of severity test could be found in O'Keeffee $v$. Ireland when Court concluded that 20 sexual assaults on 9 year old victim administered by her teacher in 6 month period amount to ill-treatment within the scope of Article $3 .{ }^{38}$ Due to the fact that this was not contested, the Court did not engage in further scrutiny

33 Škorić, M., Obiteljsko nasilje u praksi Europskog suda za ljudska prava s posebnim osvrtom na presude protiv Republike Hrvatske, Hrvatski ljetopis za kaznene znanosti i praksu, vol. 25, no. 2, 2018, p. 394

34 Mowbray, A., Cases, Materials, and Commentary on the European Convention on Human Rights, Oxford University Press, Oxford, 2012, p. 195

35 According to the partly dissenting opinion of Judge Serghides in Khlaifia and Others v. Italy, the Convention as a living instrument principle, together with the principle of effectiveness, has formed the "bedrock" of Court's evolutive interpretation

36 Separate opinion of Judge Serghides in Judgment Volodina v. Russia (2019), $\$ 4$; Al-Saadoon and Mufdhi v. The United Kingdom (2010), \$119; Concurring opinion of Judge Villiger in Davydov and Others v. Ukraine (2010); Hénaf v. France (2004), \$ 55; Öcalan v. Turkey (2005), \$193-194; Selmouni v. France (1999), $\$ 101$

37 Judgement $A$ and $B v$. Croatia, op. cit., note 17, $\$ 110$

38 Judgement O'Keeffe v. Ireland, op. cit., note 18 
whether the assaults amount to torture, inhuman or degrading treatment. This is particularly surprising given that the lack of particular assessment is contrary to the Court's position that "the right to human dignity and psychological integrity requires particular attention where a child is the victim of violence". ${ }^{39}$

Non-derogable and absolute nature of the Article 3 rights has placed them at the top of the hierarchy scale of Convention rights. Scholars predominantly agree that the Court has created a well-established practice according to which the prohibition of Article 3 ill-treatments is an absolute right in all its applications, and to invoke its protection, the threshold of severity has to be met. ${ }^{40}$ If the violation of personal integrity of a child does not amount to severity needed under this threshold, the CSA may constitute a violation of the right to respect for private life under Article 8, which is, as to its interpretative character, a less protected right. Therefore, there should be a clear margin of severity between the CSA acts that present a breach of Article 3 and Article 8. However, the analysis has showed that there is a complete absence of this normative distinction in ECtHR jurisprudence. While in certain cases the Court explicitly reiterates that the acts of sexual abuse of a child undoubtedly meet the threshold of Article 3, the explanation why there is a need to consider it as well as a privacy violation is unfortunately missing. ${ }^{41}$ Moreover, the Court has applied two different approaches with respect to its reasoning. In certain cases, the factual and legal substrate is analyzed in a separate part of the judgment dedicated solely to Article 3 and solely to Article $8 .^{42} \mathrm{In}$ more recent decisions, the Court has abandoned the clear-cut analysis due to the fact that boat provisions are assessed simultaneously under the presumption that the violation of child's sexual integrity might present at the same time a breach of Articles 3 and 8 of the Convention. One of the possible explanations for this phenomenon could be related to Court's recent policy of benefiting the children and the other vulnerable members of society from state protection where their physical and mental well-being are threatened. ${ }^{43}$ In order to strengthen child rights protection, the Court in Strasbourg has departed from previous canons of Article 3 and Article 8 division and developed a double clause strategy. Although the recent shift in judicial reasoning techniques is justified by the rule requiring that

39 Judgement $A$ and $B$ v. Croatia, op. cit., note 17, $\$ 111$; C.A.S. and C.S. v. Romania, op. cit., note $18, \mathbb{\$}$ 82

40 Omejec, J., Konvencija za zaštitu ljudskih prava i temeljnih sloboda u praksi Europskog suda za ljudska prava, Strasbourški acquis, Zagreb, 2013, p. 912

41 Judgement C.A.S. and C.S. v. Romania, op. cit., note 18, $\$ 73$

42 Judgement D.P. \& J.C. v. The United Kingdom, op. cit., note 6; Y.v. Slovenia, op. cit., note 18

43 Guide on Article 8 of the European Convention on Human Rights, Right to Respect for Private and Family Life, Home and Correspondence, Council of Europe, European Court of Human Rights, Strasbourg, 2019 , p. 13 
the Court is master of the characterization to be given in law to the facts of the case, the noted approach has not gained an unconditional support from human rights professionals. The Strasbourg Court was criticized for a lack of transparent guidance, consistency in ruling and interpretative confusion. ${ }^{44}$ Except for noted practical and theoretical implications, the Court decision whether to examine the CSA complaints under Article 3, Article 8 or both normative provisions, reflects on the typology and scope of state's positive obligations to protect children from sexual abuse.

With respect to prohibition of outrages upon personal integrity and dignity of a child, the state has a negative obligation to sustain from inflicting harm on children under state control (e.g. in detention centres, social welfare institutions, schools, hospitals or in other state institution). ${ }^{45}$ Although in recent years much of attention is given to CSA at the institutional level, there is not a single case in which the ECtHR has found the breach of state's negative obligations to refrain from ill-treatment. According to the ECtHR case law, the sexual abuse of children predominantly occurs in relationships between individuals not involving the state. The traditional understanding of human rights invoking state commitments of negative character, therefore, has been completely disregarded in Strasbourg jurisprudence related to CSA and prohibition of child ill-treatment. Furthermore, demanding standards on state parties were imposed in the area of positive obligations to protect children from sexual assaults at the hands of private actors. In a certain number of decisions, the Court has concluded that Article 3 imposes an obligation upon states to take protective measures in order to prevent subjecting persons within their jurisdictions to ill-treatment even if the ill-treatment is administrated by private individuals. ${ }^{46}$ Besides, the adoption of effective measures in the sphere of the relations of individuals between themselves can be rightfully expected from a state as to comply with the positive obligations arising from $\mathrm{Ar}$ ticle $8 .{ }^{47}$ The vertical and the horizontal effects are both, hence, embodied within the Article 3 and 8 of the Convention. If the state fails to implement measures in order to prevent offenders from committing sexual offences against children or to reply to, investigate and remedy the sexual abuse that already happened, the failure for not taking necessary steps leads to state's responsibility for the violation of the Convention.

44 O'Mahony, C., Child Protection and the ECHR: Making Sense of Positive and Procedural Obligations, International Journal of Children's Rights, vol. 27, 2019, p. 668-669

45 Judgment Blokhin v. Russia (2016)

46 M.C. v. Bulgaria, op. cit., note 18; Y. v. Slovenia, op. cit., note 18

${ }_{47} X$ and $Y v$. the Netherlands, op. cit., note 16; See also Buxton, R., Private Life and the English Judges, Oxford Journal of Legal Studies, Vol. 29, No. 3, 2009, p. 413 


\subsection{The Adequacy of Legal Framework to Protect Children from CSA}

A wide variety of measures might be appropriate to fulfil state's duty to secure prohibition of ill-treatment of children and respect for their private life. Depending on the issues covered within the particular CSA case, states enjoy different levels of margin of appreciation in protecting and guaranteeing children's right not to be sexually abused. The margin of appreciation doctrine, according to scholars, is an important tool to reach consensus on level of rights' protection and appropriateness of state positive obligations when legal traditions and cultures interact or collide. ${ }^{48}$ While we have to share the unanimous conclusion that rights from the Convention are universal human rights recognised throughout Europe, national differences in standards of their protection are acceptable if are within the margin allowed to the state. The idea behind the doctrine of margin of appreciation when positive obligations are concerned has been to recognise a certain amount of state discretion in deciding on the means of protection according to state's constitutional values and legal traditions. If asked to act and develop a policy, the states should enjoy some leeway. ${ }^{49}$ Unfortunately, the Court's review process does not offer a clear guidance on what is the precise amount of state's discretion. The noted ambiguity may cause uncertainty about what is exactly expected from the state parties to comply with the obligation, however, a rule - the more important right or freedom the narrower margin of appreciation, might shed some light on this issue.

The above mentioned rule should have been taken into account in M.C. v. Bulgar$i$, a leading case on state's positive obligations in CSA situations in the Strasbourg case law. The case involved an applicant who alleged that she had been raped by two men two months before her $15^{\text {th }}$ birthday. After two and a half years of criminal investigation, the case was officially closed due to insufficient evidences to conclude that sexual intercourses were unwilling and committed by threats or force. According to the applicant, Bulgarian law and practice in rape cases were defective due to the fact that victim's active resistance was a key condition to prosecute the offenders. Defective prosecutorial and court jurisprudence taken together with the ineffective investigation in her own case amounted to a violation of state's positive obligation to protect her physical integrity and private life. The Court acknowledged that states undoubtedly enjoy a wide margin of appreciation when deciding about the means to adequately protect individuals against rape within their jurisdiction bearing in mind that means have to be defined according to cultural

\footnotetext{
48 Gerards, J., Margin of Appreciation and Incrementalism in the Case Law of the European Court of Human Rights, Human Rights Law Review, vol. 18, 2018, p. 498

49 Lemmens, K., The Margin of Appreciation in the ECtHR's Case Law. A European Version of the Levels of Scrutiny Doctrine?, European Journal of Law Reform, vol. 20. no. 2-3, 2018, p. 90
} 
factors, local circumstances and traditional approaches. ${ }^{50}$ Although we can expect divergent national standards in the area of rape protection, the Court's conclusion not to narrow state's margin of appreciation is problematic for different reasons.

First of all, it contradicts its own conclusion that in this particular case, the fundamental values and essential aspects of private life are at stake, and consequently, effective deterrence against rape demands effective criminal law provisions. ${ }^{51}$ One of the basic principles of the doctrine of criminal law is a position that in a democratic society criminal law serves as a last resort in order to protect certain constitutional value, i.e. the ultima ratio societatis principle. The criminal law and application of sanctions are, therefore, the exact implementation of the state's ius puniendi. Consequently, in cases involving the state's positive obligations within the criminal law normative framework, the margin of appreciation has to be narrow. Moreover, the constraints on the doctrine of margin of appreciation have to be imposed in order to apply more intensive review. There should be a greater clarity in ECtHR review standards involving the state's criminal law provisions especially if the provisions refer to children and other vulnerable individuals entitled to effective protection. The stronger scrutiny has to be applied also in case if the provisions are assessed under Article 3 of the Convention. We have to bear in mind that the margine of appreciation doctrine will be abandoned in most Article 3 cases due to the absolute and non-derogable nature of rights arising from that article. However, the theoretical position on the margin of appreciation applicability in the ambit of child applicant's rights under the Convention was not followed in M.C. v. Bulgaria case. Due to the fact that there was no clear demarcation line between the alleged rape as a violation of Article 3 or Article 8 rights, the Court's standard of review, which should have elucidated the margin of appreciation doctrine, seems a quite ambiguous and incomplete.

The above detected problems relate to the general uncertainty that rules over the positive obligation standards in ECtHR case law. The role of causation presents another issue, which adds to the ambiguity flowing from the Court's practice. In order to find the link between the harm suffered by the 14 year old applicant and Bulgarian government's omissions, the ECtHR has relied on the significant flows test. According to the Court, its task was to scrutinize "whether or not the impugned legislation and practice and their application in the case at hand, combined with the alleged shortcomings in the investigation, had such significant flaws as to amount to a breach of the respondent State's positive obligations under Articles

\footnotetext{
50 Judgment M.C. v. Bulgaria, op. cit., note 18, $\$ 154$

51 Judgment M.C. v. Bulgaria, op. cit., note $18, \$ 150$
} 
3 and 8 of the Convention." ${ }^{52}$ In another words, in order to confirm a breach in state's positive obligations, the Court has to establish significant, not ordinary, common or more expected flaws, errors and omissions, in national legislation and its application. Although the introduction of the significant flaws test could have meaningfully illuminated state's liability for omissions under the Convention, the Court's assessment related to the test rests here. As Lavrysen rightfully concluded, the notion of significant flows in the remaining paragraphs of the judgment was not used, nor it was revealed what had to be understood by this notion. ${ }^{53}$ The Court has simply concluded that positive obligations arising from Article 3 and 8 were not met because the lack of resistance by the applicant was transformed in the defining element of the rape offence and because the investigation was not conducted in a context-sensitive but rather restrictive manner. ${ }^{54}$ The wording of the norm itself was not problematic, but in fact the issue arose from its interpretation by prosecuting authorities. Consequently, the M.C. v. Bulgaria ruling does not oblige state parties to the Convention to criminalise rape in a pure voluntaristic sense but rather to relinquish the criminal prosecution practice built on evidence of victim's resistance. The core of judicial review outcome in this particular case has been wrongly interpreted many times and manipulatively used in nomeans-no debate in the national legislation area, which led to new doctrinal and practical problems and a lowering of standards on protection of sexually abused victims..$^{55}$ It seems that the absence of precise guidelines on causation by omission when criminal legislation is invoked is a result of Court's simple assumption that criminalisation of rape contributes to better protection of human rights. ${ }^{56}$

52 Judgment M.C. v. Bulgaria, op. cit., note $18, \S 167$. The significant flaw test was also used in the M.G.C. v. Romania judgment, op. cit., note $18, \$ 60$

53 Lavrysen, L., No 'Significant Flaw' in the Regulatory Framework: E.S. v. Sweden and the Lowering of Standards in the Positive Obligations Case-Law of the European Court of Human Rights, Human Rights \& International Legal Discourse, vol. 7, no. 1, 2013, pp. 153-154

54 Judgment M.C. v. Bulgaria, op. cit., note 18, \$177, 182

55 No matter the warnings from scholarly contributions which have confirmed certain negative outcomes of voluntarist conception of sexual offences in legal theory and court practice, in 2019 Criminal Code Amendments the Croatian legislator has introduced the new definition of offence of rape. The rape is now identified with the offence of non-consensual sexual intercourse from Article $152 \$ 1$ of the Criminal Code previously in force, and consequently, the act of rape consists of any sexual intercourse or a sexual act equated with sexual intercourse without victim's consent. For more information related to the offence of rape in Croatian criminal law doctrine and court practice, see Vuletić, I.; Šprem, P., Materijalnopravni aspekti kaznenog djela silovanja u hrvatskoj sudskoj praksi, Policija i sigurnost, vol. 28, no. 2, 2019, pp. 130-155; Rittossa, D.; Martinović, I., Spolni odnošaj bez pristanka i silovanje - teorijski i praktični problemi, Hrvatski ljetopis za kazneno pravo i praksu, vol. 21, no. 2, 2014, pp. 509-548

56 Stoyanova, V., Causation between State Omission and Harm within the Framework of Positive Obligations under the European Convention on Human Rights, Human Rights Law Review, vol. 18, 2018, pp. $343-$ 344 
In accordance with the principle od subsidiarity, state parties have a primary responsibility to secure the rights and freedoms under the Convention, and therefore, the national legal framework, as it was demonstrated in M.C. v. Bulgaria, should provide efficient criminal law provisions to address the sexual abuse of children. In less serious cases of violation of psychological integrity the civil law remedy may suffice. Nevertheless, what if a repugnant act was not covered by any criminal or civil law norm and the question of effectiveness cannot be imposed because the norm simply does not exist? The Court has resolved the dilemma in Söderman v. Sweden.owever, $\mathrm{Ho}^{57}$ The case involved applicant's allegations that the Swedish legal system did not provide measures to protect her against stepfather's actions who covertly tried to film her in a bathroom while she was undressing before taking a shower for sexual purposes. At the time of the incident, the applicant was 14 years old. The Court reiterated that the acts in question had constituted a violation of the applicant's personal integrity. She was affected in highly intimate aspects of her private life as to considerable aggravated circumstances (the applicant was a minor, the incident had taken place in her family home, the offender was a person whom she was entitled and expected to trust), and therefore, the Court departed from the standing in M.C. v. Bulgaria and concluded that the margin of appreciation allowed to the state was narrower. ${ }^{58}$ Moreover, the Strasbourg Court also decided to partially reject the significant flaw test. While the test is considered to be "understandable in the context of investigations, (it) has no meaningful role in an assessment as to whether the respondent State had in place an adequate legal framework in compliance with its positive obligations under Article 8 of the Convention since the issue before the Court concerns the question of whether the law afforded an acceptable level of protection to the applicant in the circumstances." ${ }^{9}$ The acceptable level of protection was the new standard that replaced the significant flaw test, but again, no additional guidelines were provided by the Court, either as to the determination of its particular criteria, or as to the assessment of the exact level of burden on the state. Is the test another in casu constitutional standard related to positive obligations or decisive criterion generally applicable in CSA cases, the answer to this question solely depends on Court's judicial activism and creativity in cases that will fallow. ${ }^{60}$

57 Judgment Söderman v. Sweden, op. cit., note 18

58 The same approach was applied in the M.S. $v$. Ukraine, op. cit., note 18, \$59

59 Judgment Söderman v. Sweden, op. cit., note 18, $\$ 79,86,91$

60 The acceptable level of protection test was a starting point of the Court's interpretative journey in Škorjanec $v$. Croatia (2017) and Irina Smirnova v. Ukraine (2017). In the latter case, the ECtHR applied the test while assessing the adequacy of Ukrainian non-criminal legal framework to provide protection against intrusions on applicant's privacy and enjoyment of home 


\subsection{The Effectiveness of the Legal Framework Implementation in Practice}

As it was shown in the above presented text, Article 3 and 8 of the Convention place fairly demanding obligations upon national authorities to prevent, replay to, investigate and remedy the infringement of sexual integrity of children. The procedural layer has been added to the scope of the right to personal integrity and dignity and the right to private life as to erode the procedural injustice that applicants may encounter while seeking protection in national justice systems. Except from fulfilling substantive positive obligations, the states, therefore, have to establish procedural safeguards against unfairness in the course of a judicial procedure. The effective deterrence against sexual abuse of children goes hand in hand with the effective investigation of CSA complaints in order to achieve a coherent, meaningful and comprehensive protection for the rights of children not to be sexually abused. In C.A.S. and C.S. v. Romania the ECtHR has pointed out that the right to an effective official investigation into the alleged sexual abuse of a child extends to cases in which the abuse has been inflicted by private individuals. The Court has also offered specific explanations what elements have to be fulfilled in order to have an "effective" investigation. The inquiry is regarded as an effective if "capable of leading to the establishment of the facts of the case and to the identification and punishment of those responsible. This is not an obligation of result, but one of means." ${ }^{11}$ The core issue in the procedural obligation of effective investigation concerns the manner and length of conducting the investigation, not the final result. ${ }^{62}$ No one hast the right to demand from state agents to prosecute a specific individual and to conclude the investigation and court proceedings with a conviction judgment. The Court's focus is always been on maintenance of a proper standard of protection.

In the light of the principle that positive obligations should not impose excessive burden on the state parties to the Convention, the Court has restated in a number of cases that the procedural authorities are under obligation to take reasonable steps available to them to secure the evidence regarding the incident including but not limited to eyewitness testimony, forensic evidence etc. ${ }^{63}$ The standard of reasonableness, hence should be interpreted within the margin of national criminal procedural justice and in the light of available evidence. The ECtHR has a sub-

${ }_{61}$ Judgment C.A.S. and C.S. v. Romania, op. cit., note 18, $\$ 69,70$

62 Stoyanova, V., Due Diligence versus Positive Obligations: Critical Reflections on the Council of Europe Convention on Violence against Women, in: Niemi, J.; Peroni, L.: Stoyanova, V. (eds.), International Law and Violence Against Women: Europe and the Istanbul Convention, 2020, [https://ssrn.com/ abstract $=3384607]$, accessed 15 . April 2020

63 Judgement $A$ and $B$ v. Croatia, op. cit., note 18, $\$ 108$; C.A.S. and C.S. v. Romania, op. cit., note $18, \$$ 70; M.S. v. Ukraine, op. cit., note $18, \$ 63 ;$ Y. v. Slovenia, op. cit., note 18, \$96 
sidiary role in assessing evidence and no power to replace the procedural authorities in the evaluation of the facts of the case. The Court's scrutiny is, first of all, focused on the question whether the procedural steps taken to obtain and evaluate evidence amount to shortcomings in the investigation prohibited under the procedural aspect of a certain right. Current research has acknowledged that in most CSA cases the signs of child abuse are unclear and the only direct evidence of the crime will be the child statement. ${ }^{64}$ This could pose a problem bearing in mind that the truth-seeking system generally prefer direct evidence to circumstantial evidence. ${ }^{65}$ Therefore, it is no surprise that the Court acknowledged that the national authorities had been faced with a difficult task while conducting the investigation. It cannot be contested that CSA cases are embroiled with sensitivity often arising from conflicting versions of events, inconclusive expert opinions and nonexistence of physical evidence supporting either the applicant's or alleged offender's version of the events. ${ }^{66}$ However, the Court's recognition of difficulties in investigating and prosecuting sensitive matters is not used as a basis for applying more lenient approach to the effectiveness of the investigation when procedural obligations are concerned. In $Y$. v. Slovenia the Court precisely stated that in case of allegations under Article 3, a particularly thorough scrutiny has to be applied, even if certain domestic proceedings and investigations have already taken place. ${ }^{67}$ The exercise of investigation powers by state authorities and officers must therefore be subjected to strict scrutiny for compliance with procedural standards arising from the freedom from ill-treatment. Bearing in mind that the fundamental importance of the privacy rights under Article 8 is to a certain extent diminished with respect to Article 3, the standard of review for procedural requirements implicit in Article 8 should be less demanding.

The analysis of Court's decisions in CSA cases has showed that the clear distinction between the standards of review related to Article 3 and Article 8 is unfortunately missing. For example, in C.A.S. and C.S. v. Romania the Court held that the national judicial authorities' lack of effort to weigh up the conflicting evidence and establish the facts by engaging in a context-sensitive assessment in a case involving sexual violence against a 7 year old boy augmented to failure to carry out an effective investigation. Additional factors influencing the Court's decision were related to the fact that the investigation had not started promptly, nor was

\footnotetext{
64 Harlin Goodno, N., Protecting Any Child: The Use of the Confidential-Martial-Communications Privilege in Child Molestation Cases, University of Kansas Law Review, vol. 59, no. 1, 2010, p. 25

65 Heller, K. J., The Cognitive Psychology of Circumstantial Evidence, Michigan Law Review, vol. 105, no. 2, 2006, p. 255

66 Judgement $A$ and $B$ v. Croatia, op. cit., note 17, $\$ 127 ;$ Y. v. Slovenia, op. cit., note 18, $\$ 97$

67 Judgement Y.v. Slovenia, op. cit., note 18, \$96
} 
conducted in a reasonable time. Three weeks passed before medical examination of the boy was ordered and additional 2 months before an official statement was taken from the main suspect. After 5 years, the procedural authorities officially closed the investigation, and 7 years after the incident, the alleged offender was exonerated. To much weight was given to the fact that boy's family had not immediately reported the offences and, to a certain extent, that he had hesitated in reporting the abuse. The investigation was neither prompt, nor rigorous or child sensitive bearing in mind the length of the procedure and domestic authorities' failure to understand vulnerability and psychological reactions of sexually abused children. ${ }^{68}$ While Court's judicial reasoning was created upon factual interpretation and terminology related to procedural effectiveness, sensitivity and child vulnerability, contemporary constitutional standards regarding the procedural obligations inherent in Article 3 and Article 8 were simply merged and left without any particular clarity of the judicial review. The standards of review are even less understandable if we compare a highly similar language used in M.S. v. Ukraine where the Court held that insufficiently thorough inquiry burdened with a 2 year delay in securing the statement of allegedly abused child, unjustified number of decisions discontinuing investigation and excessively lengthy proceedings has only constituted a violation of Article $8 .^{69}$

The general uncertainty that clouds judicial review standards concerning the procedural obligations can be noted in other CSA cases discussed in front of the ECtHR. The restrictive approach in the prosecution of rape of a 14 year old girl the Court in Strasbourg proved relaying on reasonable arguments and a lack of Government's disproval in M.C. v. Bulgaria. ${ }^{70}$ Consequently, the less demanding standards of reasonable grands were applied during the assessment of both Article 3 and Article 8 procedural obligations, which is, again, contradictory to the logic of Court's reasoning on "thorough scrutiny", the stricter standard of review than the reasonableness test. ${ }^{71}$ The omissions in investigation like domestic court's inability to assess all the surrounding circumstances (i.e. evidences on environmental coercion, credibility of defence witnesses), to attach enough weight to the particular vulnerability of sexually abused child and handle the investigation without significant delays led the ECtHR to conclude that Bulgarian criminal justice system was defective and fell short of the requirements of effective investigation and prosecution of CSA cases. Similarly, a predominant practice of not making content-

${ }_{68}$ Judgment C.A.S. and C.S. v. Romania, op. cit., note $18, \$ 78-81$

69 Judgment M.S. v. Ukraine, op. cit., note 18

70 Judgement M.C. v. Bulgaria, op. cit., note 18

71 For more information on different layers of strict scrutiny test and reasonable grounds test, see Sinnar, S., Rule of Law Tropes in National Security, Harvard Law Review, vol. 129, no. 6, 2016, p. 1605 
sensitive assessment of the evidence in CSA cases in Romania was declared to be a breach of positive obligations inherent in Article 3 and 8 in M.G.C. v. Romania, another groundbreaking case. In the ambit of domestic courts' practice, a failure to take into consideration chid-specific relations to trauma and sensitively assess the fact that the victim did not disclose the abuse to her parents or did not scream for help during the incident presents a direct breach of Romania's positive obligations under both Articles 3 and $8 .^{72}$ Although blurring the standards of review is a point of contention, the Court's judgments are illuminating for the task of child-sensitive assessment, the positive obligation standard forged in the ambit of research conclusions in the child psychology and depth and rigour of the criminal justice assessment.

A certain pathway which will lead us closer to more clarity on the judicial review standards in Article 3 and 8 procedural obligations might offer the case of $Y . v$. Slovenia. ${ }^{73}$ The case concerned allegations of sexual assaults on a 15 year old girl by a 40 year older family friend. A number of longer periods of complete inactivity, some of which were contrary to the domestic procedural rules, together with the excessive length of the proceedings were used as a factual basis for the Court to conclude that procedural obligations under Article 3 were not fulfilled. The Article 8 of the Convention was invoked in relation to completely different issue - the protection of the applicant's personal integrity in the criminal proceedings. The violations of Article 3 were related to the "classical" procedural issues while allegations of a breach of Article 8 concerned facts that are specific to the personal integrity within the privacy domain. The judicial reasoning in $Y . v$. Slovenia is, therefore, more consistent with the canon of legal certainty. This was possible due to the fact that for the first time in its practice, the Court in Strasbourg examined the right to respect for private life and child victim's personal integrity in the context of the manner in which the victim had been questioned during the criminal proceedings. The normative substance of victim's Article 8 rights was observed in the light of procedural safeguards guaranteed to the accused abuser under Article $6 \$ 3$ (d). Although the Court's scope was "to strake a fair balance" between these rights ${ }^{74}$ no balancing test was performed. While scrutinising the domestic criminal proceedings, the ECtHR accepted the conclusion that the right to a fair trial had required an opportunity for the accused to cross-examine the applicant, a young woman at the time of questioning, bearing in mind that her testimony had been the only direct evidence and other gathered evidence, conflicting. The personal cross-examination by the accused was not in and of itself a violation of

\footnotetext{
Judgment M.G.C. v. Romania, op. cit., note $18, \$ 70$

Judgment $Y$. v. Slovenia, op. cit., note 18

Judgment $Y$. v. Slovenia, op. cit., note 18, $\$ 104$
} 
victim's Article 8 rights but the manner of questioning raised a serious concern. The length of questioning of 4 trial hearings over 7 months and quality of questions aimed at attacking the applicant's credibility and degrading her character were a primary cause of distressing experience for the applicant. In the presence of risk of further traumatisation of the victim, domestic courts had to, but failed, "to subject personal cross examination by the defendant... to most careful assessment, the more so the more intimate the questions are... Cross-examination should not be used as a means of intimidating and humiliating witnesses... It was first and foremost the responsibility of the presiding judge to ensure that respect for the applicant's personal integrity was adequately protected at the trial." ${ }^{\prime 5}$ Relaying on research conclusions related to secondary victimisation of sexually abused victims, the Court has extended the procedural obligation of national courts to apply the sensitive approach to the conduct of the criminal proceedings involving child victims and witnesses. Factors that created particular sensitivity and called for additional procedural authorities' actions were the pre-existing relationship between the applicant and the victim, her young age at the time of the offence and the intimate nature of the subject matter. Once again, the judicial activism of the Court was rooted in interdisciplinary research outcomes, and consequently, the judicial discretion in $Y$. v. Slovenia was limited as it may be by rigour of scientific argumentation.

\subsection{The Historic v. Activist Approach}

Professional and academic research results were of crucial importance to create the Court's guiding principles of state's responsibility to ensure the protection of children from sexual abuse in the primary education system under Article 3 of the Convention in O'Keeffe $v$. Ireland. Relying on 4 different reports revealing statistical evidence of prosecutions and complaints made to state authorities about the CSA in Ireland, the Court acknowledged that the state was aware of the level of sexual offences against children and the risk of sexual abuse within the educational settings if there was no appropriate mechanism of their protection back in 1973. The conclusions were part of the causation test and determination whether the state had, or ought to have had, knowledge of the risk of sexual abuse of children by teachers in the National Schools, and whether the state, being aware of the risk, took reasonable steps and applied effective measures to protect children from such risk. While affirmatively answering both questions, the O'Keeffe v. Ireland judgment stands out in the Court's case law for couple of different but interrelated reasons. First of all, this is the only Strasbourg Court's decision that concerns a

75 Judgment Y.v. Slovenia, op. cit., note 18, \$106; 108-109 
general risk of sexual abuse to unidentified children. ${ }^{76}$ There was no dispute that the applicant in the age of 9 had been subjected to approximately 20 sexual assaults for around 6 months by the principal of a primary school run by the Catholic Church. She complaint that the state had failed to organise its primary education system to ensure protection of children from ill-treatment. Furthermore, the risk was assessed from the point of view of facts and standards existing in 1973. The judicial reasoning was built on cannons of historical interpretation as a sign of fairness bearing in mind the fact that the level of public awareness in society today of CSA in educational institutions is considerably higher that it was at the material time.

The factual and legal context of the O'Keeffe $v$. Ireland has attracted a considerable scientific attention and the judgment was subjected to the critical analysis in a short time. Although the outcome of the case was not disputed, scholars have argued that the holding was to broad and that it created uncertainty in the interpretation of inherent positive obligations. ${ }^{77}$ In the light of the fact that risk of CSA does not have to be real and immediate, the causation standard is broader than the one in the context of protective positive obligations from earlier Court's practice, ${ }^{78}$ and it is left quite unclear why Ireland should have known of the risk in the National Schools. The above mentioned official reports were concerned with the widespread nature of the CSA in Ireland, however, none of them referring to the case of conviction from the 1920s to 1973 in which a primary school teacher was found guilty for sexually assaulting a pupil. ${ }^{79}$ The criticism is consistent with research findings according to which most of the alleged abuse occurred between the 1950s and the mid-1970s, nevertheless, national investigations emerged in the past 3 decades. ${ }^{80}$ Furthermore, the Court's methodology in historical interpretation raised concern vis-à-vis the historical application of the Convention. The Court's reasoning suffers from serious flaws due to the fact that the Court referred to international documents as a source of Ireland's obligations in 1973 that were

76 O'Mahony, op. cit., note 44, p. 669

77 Lee, H., O'Keeffe v. Ireland: The State's Obligation to Protect Children from Sexual Assault in State Schools, Boston College International and Comparative Law Review, vol. 40, no. 3, 2017, p. 39

78 Gallen, J., O'Keeffe v Ireland: The Liability of States for Failure to Provide an Effective System for the Detection and Prevention of Child Sexual Abuse in Education, The Modern Law Review, vol. 78, no. 1, 2015, p. 158

79 Keane, R., O'Keeffe v. Ireland in Strasbourg: Punishing the Guilty, Dublin University Law Journal, vol. 38, no. 1, 2015, p. 187

80 Gallen, J., Jesus Wept: The Roman Catholic Church, Child Sexual Abuse and Transitional Justice, International Journal of Transitional Justice, vol. 10, 2016, p. 335 
ratified in $1989 .{ }^{81}$ The Convention was not interpreted by majority as understood in 1973 and as then in force. At that time, there was no relevant case law to support the majority's view of the scope and nature of positive obligations at issue. For example, the hypothesis on vulnerability, its nature and gradation across the spectrum of Convention rights, has been invoked in the doctrinal discussion and ECtHR case law in last 2 decades. Although the universal fairness demands imposing obligations on states to ensure protection of children from ill-treatment in a primary education through the adoption of detection and reporting mechanisms, particularly when the abuser exploits authority over the child, the cost of confirming such positive obligations should not be lowering the standards of judicial review. As judges in dissent pointed out, "the standards of today based on experience up to today are not necessarily how conduct in the past is fairly to be judged." ${ }^{2}$

A clear example of the evolutive outcome of judicial review standards is the last year's judgment of the ECtHR $A$ and $B v$. Croatia. Unlike the O'Keeffe v. Ireland, the judgment is not preoccupied with the past, rather it stands out as potentially the most coherent Court's decision that illuminates a substantive nature of sexually abused children's rights under the Convention and their reach and practical recognition in regard to positive obligations of the state parties and the Court itself. In its 6 decades of practice, the Court for the first time issued a request to the Bar Association of a member country for appointment of a separate representative to overcome a strong risk of invoking the rights of the applicant child in an instrumental way by her parents who were in a mutual conflict and incompetent to protect the best interest of their child. The representative was trusted with the task to duly present child's views and interests due to the fact that the alleged abuser of a 4 year old girl was her father. Although the Convention nor the Rules of the Court regulate the issue who should represent the child under such circumstances, the Court has decided to fill the lacuna with ad hoc solution relying on the relevant European rules within the context of child friendly justice. ${ }^{83}$ The concept of child friendly justice is a normative umbrella that merges rules from different legal

81 In his concurring opinion, Judge Ziemele has warned the majority that two International Human Rights Covenants (i.e. the ICCPR and the ICESC) were adopted in 1966, Ireland signed them in 1973 and ratified them even later, in 1989

82 Joint partly dissenting opinion in O'Keeffe v. Ireland, op. cit., note 18

83 Art. 24 of the Council Directive 2012/29/EU establishing minimum standards on the rights, support and protection of victims of crime [2012] OJ L315/57; Article $31 \$ 4$ of the Convention on the Protection of Children against Sexual Exploitation and Sexual Abuse (Konvencija Vijeća Europe o zaštiti djece od seksualnog iskorištavanja i seksualnog zlostavljanja), Official Gazette, International Agreements, No. 11/2011, 13/2011, 15/2011; Section D, 2, 37, $42-43$ of the Guidelines of the Committee of Ministers of the Council of Europe on Child-Friendly Justice 
branches and positions them in a comprehensive normative unity guided under the principles rooted in international child rights framework in order to adopt judicial and state administrative system to the specific rights, interests and needs of children. Under this concept, the child is perceived as a rights holder rather than a mere object of protection and care, ${ }^{84}$ and justice is afforded to children according to their best interest, "an interpretative principle of superior judicial consideration". 85

In $A$ and $B v$. Croatia the Court examined 3 important issues. The first issue demanded an exhaustive analysis of Croatian regulatory and legal framework to protect the applicant child's rights guaranteed under Article 3 and Article 8 of the Convention. Next, the Court was concentrated on the concrete application of the framework with respect to procedural obligations of effective investigation. The final Court's task required a meticulous assessment of state authorities' conduct in order to conclude whether applicant's rights as a child victim of sexual abuse were sufficiently taken into consideration. The enumerated issues present an essence of standards of children's rights protection form sexual abuse created over the years in ECtHR jurisprudence. Except form the fact that the Court examined everything what was possible to examine within the boundaries set by the application, the Strasbourg judicial authority clearly stated that "in cases of sexual abuse children are particularly vulnerable" ${ }^{86}$ This is an intriguing novelty having in mind that in previously delivered CSA judgments the Court's statements on vulnerability were wrapped in general rhetoric about "children and other vulnerable individuals". A common presumption has been that the youngest members of society belong to vulnerability or particular vulnerability group, nevertheless, the exact meaning and effects of its gradation as well as repercussions on other classical ECtHR institutes like the issue of causation have never been reviled. In $A$ and $B v$. Croatia the Court clearly reiterated that investigative bodies have a duty to implement the criminal law mechanisms to address "the particular vulnerability of the applicant as a child of a young age, who had allegedly been a victim of sexual abuse by her father, taking the child's best interests as a primary consideration and in this connection to afford protection to her victim's rights and avoid secondary victimisation" ${ }^{87}$ As a result, the assessment tool for evaluation of state authorities'

84 Liefaard, T., Child-Friendly Justice: Protection and Participation of Children in the Justice System, Temple Law Review, vol. 88, no. 4, 2016, p. 906

85 Mazzinghy, A., Child-Friendly Justice behind Bars: A Comparative Analysis of the Protection Mechanisms of the Rights of Arrested Children in the Practice of the Working Group on Arbitrary Detention and of the European and Inter-American Courts of Human Rights, American University International Law Review, vol. 35, no. 2, 2020, p. 325

86 Judgement $A$ and $B v$. Croatia, op. cit., note $17, \$ 111$

87 Judgement $A$ and $B v$. Croatia, op. cit., note 17, $\$ 121$ 
diligence in conducting the investigation was a three-step test that focuses on culpable disregard, discernible bad faith and a lack of will on the part of investigative or prosecuting agents. The test was already applied in M.P. and Others v. Bulgaria 7 year earlier ${ }^{88}$ however, this time, the Court has extended its application merging it with the standard of reasonableness and the best interest principle. According to the Court, "the domestic authorities did everything that could have reasonably been expected from them to protect the rights of the applicant, a child allegedly victim of sexual abuse, and to act in her best interest" ${ }^{89}$ In the Court's reasoning, it is clearly visible the tension between the child-centred approach supported by the institute of vulnerability and the best interest principle on the one hand, and, on the other, the standard of reasonableness, a more lenient causation standard which goes in line with the margin of appreciation doctrine. It seems that judicial activism in Strasbourg is considerably limited with political constraints which demand not strict but rather a reasonable implementation of ECtHR standards no matter the value of the right protected under the Convention.

\section{FINAL REMARKS}

In recent years much has been said about the role given to the ECtHR in challenging endeavour of creating the pathway to universal recognition of basic human rights. The bulk of scientific literature confirms a gatekeeper's position of this Court for maintaining a minimal level of collective enforcement of human rights and fundamental freedoms within the Council of Europe. The interpretative authority combined with a firm determination to promote European human rights values have positioned the Court in an avant-garde composition of human rights law. While relying on the dynamic interpretation of the Convention and discourse of practical and effective rights, the Court in Strasbourg has developed a clear evolutive line of human rights standards. The standards set by the Court to safeguard the rights of sexually abused children fall within the margin of evolutive approach in interpreting the rights inherent in both Article 3 and Article 8 of the Convention. The Court's judicial review methodology in CSA cases has developed gradually starting from almost incidental enumeration of guiding principles in its early case law and concluding with the comprehensive standards tailored within the context of child friendly justice. The notions of child's particular vulnerability and child sensitive assessment have become a guiding force for reinforcing specific child applicant's rights, like the freedom from ill-treatment and right to personal integrity and dignity. Interpreted together, these 2 basic rights have been used to

\footnotetext{
${ }_{88}$ Judgement M.P. and Others $v$. Bulgaria, op. cit., note 17, \$ 113

89 Judgement $A$ and $B v$. Croatia, op. cit., note 17, \$ 129
} 
create a tight net of state's positive obligations to prevent, respond to, investigate and prosecute the sexual abuse of children. In case of CSA the state has an obligation to safeguard the physical and psychological integrity of children, and in order to fulfil it, firstly, the state has to adopt an adequate legal framework with effective deterrent effect, secondly, apply the framework according to acceptable procedural standards and thirdly, take sufficient consideration of rights of sexually abused children in practice. The required obligations (TRiO) impose a quite demanding task to national legislators and prosecuting authorities, and last year, the state oriented TRiO was transformed by the Strasbourg Court itself in an obligation to appoint a separate representative for a child applicant in $A$ and $B v$. Croatia. The identification of a potential conflict of interest between parents was sufficient for the Court to create a new procedural means aimed at ensuring the independent submissions on behalf of the child as to her best interests. The set of novel standards with dual binding effect spreading over the state and ECtHR level is a clear sign of Court's potential to create and steadily upgrade a norm in the ambit of jurisprudential developments.

The noted trends in the Court's case law confirm a normative evolution legitimized by the principle that "mankind owes to the child the best that it has to give" ${ }^{90}$ However, it has to be recalled that the HUDOC search engine discovered 10 judgments related to protection of sexually abused children's rights, and this fact calls for further analysis whether the ECtHR is accessible enough to children and whether the justice it creates is child friendly indeed. The analysis has also revealed that judicial reasoning techniques used by the Court present another important concern. The Court has places child's vulnerability and sensitive approach in the centre of its doctrinal discourse, however, the explanations related to their nature and effect on other "classical" institutes is rather vague. The lack of clarity in Court's reasoning and consistency in applying constitutional principles and relevant tests can be seen in a number of examples. It is still ambiguous under which circumstances the CSA amounts to torture, inhuman or degrading treatment or only constitutes a violation of the right to respect for private life under Article 8. The level of discretion left to the states under the margin of appreciation doctrine in CSA cases has remained unclear and the rule - the more important right or freedom the narrower margin of appreciation, inconsistently applied. The absence of precise guidelines on thorough scrutiny and standard of reasonableness related to effective investigation is another sign of insufficient judicial preciseness. It seems that the Court is concentrated on setting the standard and the question of its implications is simply left to the states. Except from the fact that this strat-

90 Geneva Declaration of the Rights of the Child of 1924, adopted Sept. 26, 1924, League of Nations O.J. Spec. Supp. 21, at 43 (1924) 
egy may lower the quality of Court's reasoning, it adds to the general uncertainty that clouds the positive obligation standards in ECtHR case law. If the standards are not embodied with sufficient legal certainty, the question remains whether the Strasbourg Court protective policy has a doctrinal power to be adequately implemented within the national jurisdictions, and therefore, a potential to reach fair and just protection of children from sexual abuse within the Council of Europe.

\section{REFERENCES}

\section{BOOKS AND ARTICLES}

1. Adler, A., The Perverse Law of Child Pornography, Columbia Law Review, vol. 101, no. 2, 2001, pp. $209-273$

2. Ajduković, M. et al., Gender and Age Differences in Prevalence and Incidence of Child Sexual Abuse in Croatia, Croatian Medical Journal, vol. 54, 2013, pp. 469 - 479

3. Alderson, P., Children's rights and power, in: Jones, S., (ed.) 30 Years of Social Change, London, Philadelphia, 2018

4. Angelakis, I. et al., Childhood Maltreatment and Adult Suicidality: A Comprehensive Systematic Review with Meta-Analysis, Psychological Medicine, vol, 49, 2019, pp. 1057 - 1078

5. Azzopardi, C. et al., A Meta-Analysis of the Prevalence of Child Sexual Abuse Disclosure in Forensic Settings, Child Abuse \& Neglect, vol. 93, no. 2, 2019, pp. 291 - 304

6. Bidarraa, Z. et al., Co-Occurrence of Intimate Partner Violence and Child Sexual Abuse: Prevalence, Risk Factors and Related Issues, Child Abuse \& Neglect, vol. 55, no. 2, 2016, pp. 10 $-21$

7. Buxton, R., Private Life and the English Judges, Oxford Journal of Legal Studies, vol. 29, no. 3, 2009, pp. $413-425$

8. Collins, T. M., International Child Rights in national Constitutions: Good Sense or Nonsense for Ireland, Irish Political Studies, vol. 28, no. 4, 2013, pp. 591 - 619

9. Domhardt, M. et al., Resilience in Survivors of Child Sexual Abuse: A Systematic Review of the Literature, Trauma, Violence \& Abuse, vol. 16, no. 4, 2015, pp. $476-493$

10. Faye Jacobsen, A., Children's Rights in the European Court of Human Rights - An Emerging Power Structure, International Journal of Children's Rights, vol. 24, 2016, pp. 548 - 574

11. Gallen, J., Jesus Wept: The Roman Catholic Church, Child Sexual Abuse and Transitional Justice, International Journal of Transitional Justice, vol. 10, 2016, pp. $332-349$

12. Gallen, J., O'Keeffe v Ireland: The Liability of States for Failure to Provide an Effective System for the Detection and Prevention of Child Sexual Abuse in Education, The Modern Law Review, vol. 78 , no. 1,2015 , pp. 151 - 163

13. Gerards, J., Margin of Appreciation and Incrementalism in the Case Law of the European Court of Human Rights, Human Rights Law Review, 2018, vol. 18, pp. 495 - 515

14. Guide on Article 8 of the European Convention on Human Rights, Right to Respect for Private and Family Life, Home and Correspondence, Council of Europe, European Court of Human Rights, Strasbourg, 2019 
15. Harlin Goodno, N., Protecting Any Child: The Use of the Confidential-Martial-Communications Privilege in Child Molestation Cases, University of Kansas Law Review, vol. 59, no. 1, 2010, pp. $1-46$

16. Hébert, M. et al., Agression sexuelle et violence dans les relations amoureuses: Le rôle médiateur du stress post-traumatique, Criminologie, vol. 50, no. 1, L'agression sexuelle commise sur des mineurs: les victimes, les auteurs, 2017, pp. 157 - 179

17. Heller, K. J., The Cognitive Psychology of Circumstantial Evidence, Michigan Law Review, vol. 105, No. 2, 2006, pp. 241-305

18. Hilden, M et al., A History of Sexual Abuse and Health: A Nordic Multicentre Study, BJOG: an International Journal of Obstetrics and Gynaecology, vol. 111, 2004, pp. 1121 - 1127

19. Keane, R., O'Keeffe v. Ireland in Strasbourg: Punishing the Guilty, Dublin University Law Journal, 2015, vol. 38, no. 1, pp. 172 - 190

20. Kovčo Vukadin, I., Organizirani kriminalitet: pedofilija i prostitucija, Hrvatski ljetopis za kazneno pravo i praksu, vol. 5, no. 2, 1998, pp. 641 - 679

21. Kovco Vukadin, I., Stigmatizacija počinitelja seksualnih delikata, Zbornik Pravnog fakulteta Sveučilišta u Rijeci, vol. 24, no, 2, 2003, pp. $819-842$

22. Lavrysen, L., No 'Significant Flaws' in the Regulatory Framework: E.S. v. Sweden and the Lowering of Standards in the Positive Obligations Case-Law of the European Court of Human Rights, Human Rights \& International Legal Discourse, vol. 7, no. 1, 2013, pp. 145 - 164

23. Lee, H., O'Keeffe v. Ireland: The State's Obligation to Protect Children from Sexual Assault in State Schools, Boston College International and Comparative Law Review, vol. 40, no. 3, 2017, pp. $28-40$

24. Lemmens, K., The Margin of Appreciation in the ECtHR's Case Law. A European Version of the Levels of Scrutiny Doctrine?, European Journal of Law Reform, vol. 20. no. 2-3, 2018, pp. $78-96$

25. Letnar Černič, J., Impact of the European Court of Human Rights on the Rule of Law in Central and Eastern Europe, Hague Journal on the Rule of Law, vol. 10, 2018, pp. $111-137$

26. Liefaard, T., Child-Friendly Justice: Protection and Participation of Children in the Justice System, Temple Law Review, vol. 88, no. 4, 2016, pp. 905 - 928

27. Manigliol, R., Child Sexual Abuse in the Etiology of Anxiety Disorders: A Systematic Review of Reviews, Trauma, Violence \& Abuse, vol. 14, no. 2, 2013, pp. $96-112$

28. Mazzinghy, A., Child-Friendly Justice behind Bars: A Comparative Analysis of the Protection Mechanisms of the Rights of Arrested Children in the Practice of the Working Group on Arbitrary Detention and of the European and Inter-American Courts of Human Rights, American University International Law Review, vol. 35, no. 2, 2020, pp. 319 - 266

29. Mowbray, A., Cases, Materials, and Commentary on the European Convention on Human Rights, Oxford University Press, Oxford, 2012

30. O'Mahony, C., Child Protection and the ECHR: Making Sense of Positive and Procedural Obligations, International Journal of Children's Rights, vol. 27, 2019, pp. 660 - 693

31. Omejec, J., Konvencija za zaštitu ljudskih prava i temeljnih sloboda u praksi Europskog suda za ljudska prava, Strasbourški acquis, Zagreb, 2013 
32. Procaccini, K., C., Constructing the Right Not to Be Made a Refugee at the European and InterAmerican Courts of Human Rights, Harvard Human Rights Journal, vol. 22, no. 2, 2009, pp. $271-292$

33. Radić, I.; Radina, A., Zaštita od nasilja u obitelji: obiteljskopravni, prekršajnopravni i kaznenopravni aspekt, Zbornik radova Pravnog fakulteta u Splitu, vol. 51, no. 3, 2014, pp. 727 - 754

34. Rittossa, D., Kažnjavanje počinitelja najtežih seksualnih delikata na štetu djece u RH: zakonski okviri i postojeća sudska praksa, Hrvatski ljetopis za kaznene znanosti i praksu, vol. 25, no. 2, 2018, pp. $417-445$

35. Rittossa, D.; Martinović, I., Spolni odnošaj bez pristanka i silovanje - teorijski i praktični problemi, Hrvatski ljetopis za kazneno pravo i praksu, vol. 21, no. 2, 2014, pp. $509-548$

36. Rittossa, D., Seksualni delikti na štetu djece: hrvatski kaznenopravni okvir kroz prizmu zahtjeva iz Direktive 2011/93/EU, Hrvatski ljetopis za kaznene znanosti i praksu, vol. 25, no. 1, 2018, pp. $29-63$

37. Sadurski, W., Partnering with Strasbourg: Constitutionalisation of the European Court of Human Rights, The Accession of Central and East European States to the Council of Europe, and the Idea of Pilot Judgments, Human Rights Law Review, vol. 9, no. 3, 2009, pp. 397 - 453

38. Sinnar, S., Rule of Law Tropes in National Security, Harvard Law Review, vol. 129, no. 6, 2016, pp. 1566 - 1618

39. Škorić, M., Obiteljsko nasilje u praksi Europskog suda za ljudska prava s posebnim osvrtom na presude protiv Republike Hrvatske, Hrvatski ljetopis za kaznene znanosti i praksu, vol. 25, no. 2, 2018, pp. $387-415$

40. Stoyanova, V., Causation between State Omission and Harm within the Framework of Positive Obligations under the European Convention on Human Rights, Human Rights Law Review, vol. 18, 2018, pp. $309-346$

41. Vuletić, I.; Šprem, P., Materijalnopravni aspekti kaznenog djela silovanja u hrvatskoj sudskoj praksi, Policija i sigurnost, vol. 28, no. 2, 2019, pp. 130-155

42. Walker, H. et. al., The Prevalence of Sexual Revictimization: A Meta-Analytic Review, Trauma, Violence \& Abuse, vol. 20, no. 1, 2019, pp. $67-80$

\section{EU LAW}

1. Council Directive 2012/29/EU establishing minimum standards on the rights, support and protection of victims of crime [2012] OJ L315/57

\section{ECHR}

1. A and B v. Croatia, Application no. 7144/15, Judgment of 4 November 2019

2. Al-Saadoon and Mufdhi v. The United Kingdom, Application no. 61498/08, Judgment of 4 October 2010

3. Blokhin v. Russia, Application no. 47152/06, Judgment of 23 March 2016

4. C.A.S. and C.S. v. Romania, Application no. 26692/05, Judgment of 24 September 2012

5. D.P. \&.J.C. v. the United Kingdom, Application no. 38719/97, Judgment of 10 January 2003 
6. Davydov and Others v. Ukraine, Application no. 17674/02 and 39081/02, Judgment of 1 October 2010

7. European Convention for the Protection of Human Rights and Fundamental Freedoms, as amended by Protocols, Rome, 4 November 1950, ETS 5

8. Hénaf v. France, Application no. 65436/01, Judgment of 27 February 2004

9. Irina Smirnova v. Ukraine, Application no. 1870/05, Judgment of 6 March 2017

10. K.U. v. Finland, Application no. 2872/02, Judgment of 2 March 2009

11. Khlaifia and Others v. Italy, Application no. 16483/12, Judgment of 15 December 2016

12. M.C. v. Bulgaria, Application no. 39272/98, Judgment of 4 March 2004

13. M.G.C. v. Romania, Application no. 61495/11, Judgment of 15 June 2016

14. M.P. and Others v. Bulgaria, Application no. 22457/08, Judgment of 15 February 2012

15. M.S. v. Ukraine, Application no. 2091/13, Judgment of 11 October 2017

16. O'Keeffe v. Ireland, Application no. 35810/09, Judgment of 28 January 2014

17. Öcalan v. Turkey, Application no. 46221/99, Judgment of 12 May 2005

18. Selmouni v. France, Application no. 25803/94, Judgment of 28 July 1999

19. Škorjanec v. Croatia, Application no. 25536/14, Judgment of 28 June 2017

20. Söderman v. Sweden, Application no. 5786/08, Judgment of 12 November 2013

21. Volodina v. Russia, Application no. 41261/17, Judgment of 4 November 2019

22. $X$ and $Y v$, the Netherlands, Application no. 8978/80, Judgment of 26 March 1985

23. Y. v. Slovenia, Application no. 41107/10, Judgment of 28 august 2015

24. $Z$ and Others v. the United Kingdom, Application no. 29392/95, Judgment of 10 May 2001

\section{INTERNATIONAL DOCUMENTS}

1. The Council of Europe Convention on the Protection of Children against Sexual Exploitation and Sexual Abuse (Konvencija Vijeća Europe o zaštiti djece od seksualnog iskorištavanja i seksualnog zlostavljanja), Official Gazette, International Agreements, No. 11/2011, $13 / 2011,15 / 2011$

2. Guidelines of the Committee of Ministers of the Council of Europe on Child-Friendly Justice (2010)

3. Geneva Declaration of the Rights of the Child of 1924, adopted Sept. 26, 1924, League of Nations O.J. Spec. Supp. 21, at 43 (1924)

\section{WEBSITE REFERENCES}

1. Stoyanova, V., Due Diligence versus Positive Obligations: Critical Reflections on the Council of Europe Convention on Violence against Women, in: Niemi, J.; Peroni, L.: Stoyanova, V. (eds.), International Law and Violence Against Women: Europe and the Istanbul Convention, 2020, [https://ssrn.com/abstract=3384607], accessed 15. April 2020 